\title{
Inguinal pain during pregnancy, secondary to round ligament varicosities: case report
}

\author{
Gamaliel Vázquez Estudillo $^{1 *}$, Junior J. Araiza Navarro², Martin F. Tellez Romero³, \\ Rogelio Mata $\mathrm{Cruz}^{3}$, Ivanhoe Larracilla Salazar ${ }^{4}$, Alex Simon Mendoza ${ }^{5}$
}

\begin{abstract}
${ }^{1}$ General Surgery Resident at the Postgraduate School of Naval Sanity, Universidad Naval and the Hospital General Naval de Alta Especialidad (HOSGENAES), Secretaría de Marina Armada de México (SEMAR)

${ }^{2}$ Gynecology and Obstetrician Resident at the Postgraduate School of Naval Sanity, Universidad Naval and the Hospital General Naval de Alta Especialidad (HOSGENAES), Secretaría de Marina Armada de México (SEMAR)

${ }^{3}$ General Surgery Service of the Tampico Naval Regional Hospital, Secretaría de Marina Armada de México (SEMAR)

${ }^{4}$ Chief of the General Surgery Service of the Hospital General Naval de Alta Especialidad (HOSGENAES) and Associate Professor of the General Surgery Course in the Postgraduate School of Naval Sanity, Universidad Naval, Secretaría de Marina Armada de México (SEMAR)

${ }^{5}$ General Surgery Service of the Hospital General Naval de Alta Especialidad (HOSGENAES), Secretaría de Marina Armada de México (SEMAR)
\end{abstract}

Received: 24 August 2018

Accepted: 27 September 2018

\section{*Correspondence:}

Dr. Gamaliel Vázquez Estudillo,

E-mail: dr.gama.men@gmail.com

Copyright: (c) the author(s), publisher and licensee Medip Academy. This is an open-access article distributed under the terms of the Creative Commons Attribution Non-Commercial License, which permits unrestricted non-commercial use, distribution, and reproduction in any medium, provided the original work is properly cited.

\begin{abstract}
The exact incidence of round ligament varicosities (RLV) is uncertain, due to the fact that there are few cases reported in the literature, and in many cases, they can be confused with inguinal hernias. A 26-year-old female with 26.3 weeks of gestation by date of last menstruation, who went to the emergency service of the Naval Regional Hospital of Tampico with the presence of an increase in volume in the left inguinal region, accompanied by pain, which increased standing and decreasing with the dorsal decubitus, the physical examination confirmed an increase in volume at the left inguinal level. An ultrasound of the inguinal region was requested to rule out an inguinal hernia as the first diagnosis, Doppler ultrasound revealed RLV. The patient was treated conservatively and at two weeks after the resolution of the pregnancy, the RLV presented a spontaneous regression and her symptoms completely resolved. This is the first case of round ligament varicosities reported in present institution. It is important to be aware of this pathology, to perform extension studies (Doppler ultrasound) to avoid unnecessary surgery in pregnant women.
\end{abstract}

Keywords: Doppler ultrasound, Inguinal canal, Inguinal ultrasonography, Pregnant women, Round ligament, Round ligament varicosities

\section{INTRODUCTION}

The exact incidence of round ligament varicosities (RLV) is uncertain, because there are few cases reported in the literature. ${ }^{1}$ From the clinical point of view, the presence of an inguinal mass that usually associates sensation of pain is typical, so it is important to distinguish between varicose veins and hernias in order to avoid unnecessary surgery. $^{2}$

Color Doppler ultrasound is the diagnostic of choice since it avoids the use of ionizing energy during 
pregnancy and is not only useful for the diagnosis of RLV, but also used for the follow-up of patients to exclude complications of RLV, such as rupture and thrombosis of the RLV that can produce and give rise to an intense painful inflammation in the groin. ${ }^{3,4}$ This study is performed initially in the supine position and the Valsalva maneuver is important in this examination because the venous flow can decrease at rest. ${ }^{1,3}$

\section{CASE REPORT}

Authors present the case of a female patient of 26 years of age, with 26.3 weeks gestation by date of last menstruation, which went to the emergency service of the Naval Regional Hospital of Tampico with the presence of an increase in volume in the left inguinal region, accompanied by pain, which increased when standing and decreased with the dorsal decubitus, refers that this discomfort began at approximately 20 weeks gestation, however in the last days before going to medical assessment had increased symptoms, physical examination confirmed an increase in volume at the left inguinal level (Figure 1), with pain at manipulation and which was reduced only in the dorsal decubitus position.

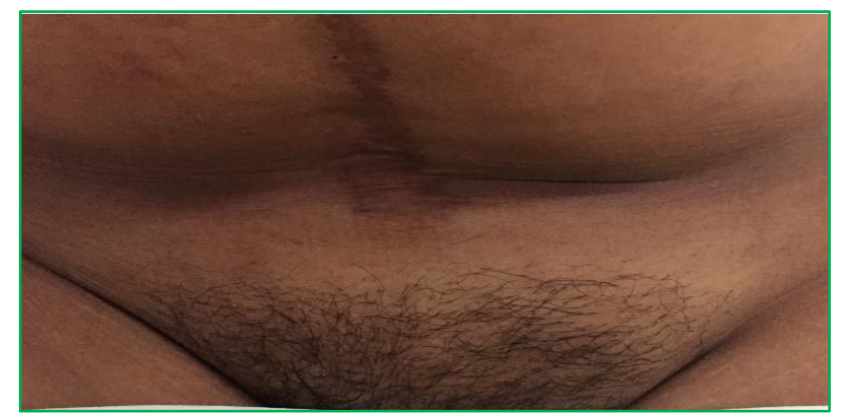

Figure 1: Anterior view of the pregnant patient, with increased inguinal volume on the left side.

An ultrasound of the inguinal region was requested to rule out an inguinal hernia as the first diagnosis, Doppler ultrasound revealed RLV, there were no intraluminal echogenic findings suggesting thrombus formation; there were no soft tissue components, no evidence of bowel loops or lymphadenopathy (Figure 2 and 3).

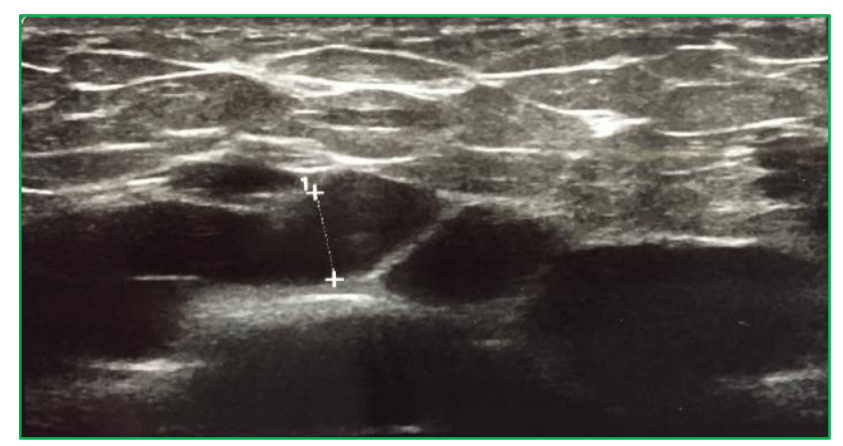

Figure 2: Round ligament varicosities (line 1), scale of frises in the ultrasound of the inguinal region.
The diagnosis of RLV was made. The patient was treated conservatively and was scheduled for cesarean section, which was performed without incident at 38 5/7 weeks gestation. Two weeks after the resolution of the pregnancy, the RLV presented a spontaneous regression and their symptoms completely resolved.

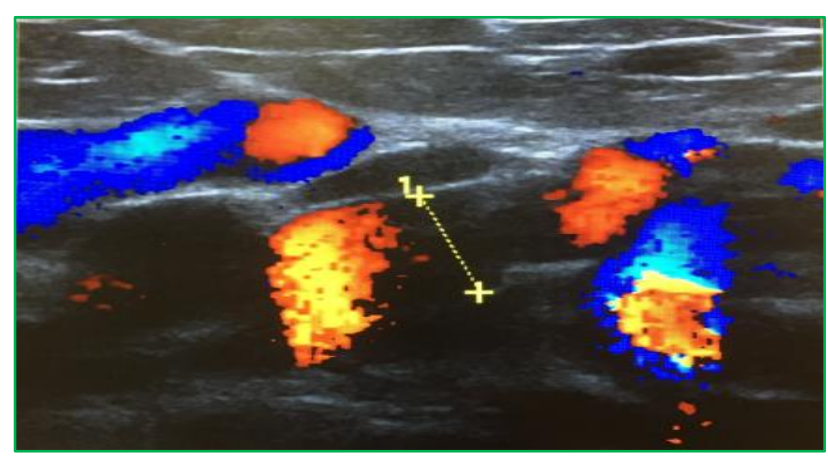

Figure 3: Round ligament varicosities (line 1) that is demonstrated in the ultrasound of the inguinal region by color Doppler.

\section{DISCUSSION}

The differential diagnosis of an inguinal mass includes hernias, adenopathy, lipomas, cysts, endometriosis and varicose veins. RLV and inguinal hernias may be clinically indistinguishable, since they may have similar presentations, Lechner et al it refers that the increase in volume in the groin that appears during pregnancy is due mostly to RLV than to inguinal hernias, even the latter could temporarily disappear during pregnancy because the enlarged uterus pushes the intestines away from the inguinal canal and by therefore it blocks the internal inguinal ring. ${ }^{5,6}$

Round ligament varicosities are a rare entity that has been described sporadically in the medical literature. ${ }^{2}$ The round ligament passes from the lateral uterus, through the internal abdominal ring, and along the inguinal canal to the labia majora. The RLV arise from the veins that drain the round ligament and the inguinal canal in the inferior epigastric vein. ${ }^{7}$ The venous system of the female pelvis is replete with multiple anastomoses that drain mostly to the internal iliac system. The large uterine and vaginal plexuses drain mainly through two or three veins in the uterine pedicle in the internal iliac veins. ${ }^{8}$

Since these veins do not contain valves, they are not fully competent, this causes them to increase in volume when making postural changes, simulating irreducibility. The presence of receptors for progesterone and estrogens in the round ligament has been demonstrated, which explains part of the pathophysiology, such as relaxation of the venous smooth muscle, causing loss of vascular resistance, high cardiac output that causes increased venous return, which eventually leads to thickening of the tributary veins and obstruction of the pelvic veins by the gravid uterus. ${ }^{9}$ 
A larger number of cases have been reported on the left side and one of the possible explanations is that obstetricians generally suggest that pregnant women sleep on their left side, mainly in the second and third trimesters. This is because it decreases the pressure on the vena cava, aorta and iliac, and increase the flow of blood to the fetus in the uterus, as well as the ease of presentation and position of the fetus in the pelvis. Due to the severity and pressure, sleeping on the left side for a long time could increase the incidence of ipsilateral RLV. ${ }^{9,10}$

As reported by Ryu KH, Yoon $\mathrm{JH}$ the main symptom in present case was the increase in volume at the groin level and the sensation of painful mass in the groin. ${ }^{4}$ Once the suspicion was made, the recommended diagnostic algorithm was performed by Lechner et al. and like Mine et al. and Yonggang et al two recent Asian studies, present case was treated conservatively and under surveillance, remitting the symptomatology after the resolution of pregnancy in a period no longer than 4 weeks. ${ }^{6,10,11}$

\section{CONCLUSION}

It is important to differentiate inguinal pain during pregnancy, keep in mind the variety of possible differential diagnoses, exhaust and make use of the extension studies that are available because a physical examination may not be enough. All this can help avoid unnecessary surgery, decreasing the risk to both the patient and the fetus.

Funding: No funding sources

Conflict of interest: None declared

Ethical approval: The study was approved by the Institutional Ethics Committee

\section{REFERENCES}

1. Uzun M, Akkan K, Coskun B. Round ligament varicosities mimicking inguinal hernias in pregnancy: importance of color Doppler sonography. Diagnost Interventional Radiol. 2010;16(2):150.

2. Copete MC, Ruiz MC, Yánez RJ, López LH. Varicose veins in the round ligament. Radiol. 2010;52(1):81-4.
3. Garcia-Paredes LF, Torres-Ayala SC, RiveraHernández W, Mojica WR. A case of round ligament varices presenting in pregnancy. Am J Case Rep. 2017; 18:1194.

4. Ryu KH, Yoon JH. Ultrasonographic diagnosis of round ligament varicosities mimicking inguinal hernia: report of two cases with literature review. Ultrasonography. 2014;33(3):216-21.

5. McKenna DA, Carter JT, Poder L, Gosnell JE, Maa J, Pearl JM, et al. Round ligament varices: sonographic appearance in pregnancy. Ultrasound Obstet Gynecol: Offic J Int Soc Ultrasound Obstet Gynecol. 2008;31(3):355-7.

6. Lechner $M$, Fortelny $R$, Öfner D, Mayer F. Suspected inguinal hernias in pregnancy-handle with care!. Hernia. 2014;18(3):375-9.

7. Reisfield DR. Varicosities in veins of the inguinal canal during pregnancy. J Med Soc New Jersey. 1962;59:24.

8. Frede TE. Ultrasonic visualization of varicosities in the female genital tract. J Ultrasound Med. 1984;3(8):365-9.

9. Cheng D, Lam H, Lam C. Round ligament varices in pregnancy mimicking inguinal hernia: an ultrasound diagnosis. Ultrasound Obstet Gynecol. 1997;9(3):198-9.

10. Yonggang $H$, Jing $Y$, Ping W, Guodong $G$, Chenxia $\mathrm{M}$, Xiaojing $\mathrm{X}$, et al. Forty-one cases of round ligament varicosities that are easily misdiagnosed as inguinal hernias. Hernia. 2017;21(6):901-4.

11. Mine Y, Eguchi S, Enjouji A, Fukuda M, Yamaguchi $\mathrm{J}$, Inoue $\mathrm{Y}$, et al. Round ligament varicosities diagnosed as inguinal hernia during pregnancy: A case report and series from two regional hospitals in Japan. Int J Surg Case Rep. 2017;36:122-5.

Cite this article as: Estudillo GV, Navarro JJA, Romero MFT, Cruz RM, Salazar IL, Mendoza AS. Inguinal pain during pregnancy, secondary to round ligament varicosities: case report. Int J Reprod Contracept Obstet Gynecol 2018;7:4762-4. 